\title{
GANGGUAN FUNGSIONAL MENETAP BERPENGARUH PADA RISIKO DEPRESI LANSIA DM DI WILAYAH KERJA PUSKESMAS JEKAN RAYA KOTA PALANGKA RAYA
}

\author{
Agnes Dewi Astuti, Reny Sulistyowati, Natalansyah \\ Prodi DIV Keperawatan Poltekkes Kemenkes Palangka Raya
}

\begin{abstract}
Aging is a a natural process in life. Aging is characterized by loss of slowly ability organ tissue repair itself and is irreversible. The elderly are the final statge of a person's life cycle and experience the aging process with change in various physical or physiological, psychological and social aspects (Miller, 2012). Hanges dues to aging eldely comple raises enormous opportunity for the elderly are at risk of depression. The objective of this study was to determine the factors that influence the risk of depression in elderly at Puskesmas Jekan Raya of Palangka Raya City with descriptive correlational research design using cross sectional approach. The sampling technique in this research is by using probability sampling technique that sampling technique giving equal oppurtinity to every individual in the population to be the research sample.The statistical test used was descriptive test and Chi Square test. The result indicate that factors influencing the risk of depression in the elderly is functional impairment were settled with $\mathrm{p}$ value $=0,000$. Conclusion of the elderly who have other diseases besides DM settle a vulnerable population at risk of depression. The most dominant factor is the functional disturbances persist after controlling the variable of age, live event $\mathrm{s}$ and other diseases (other than $\mathrm{DM}$ ) with $\mathrm{OR}=39$. Recommended in elderly nursing decision making in order to improve the health of elderly family based programs to prevent depression in the elderly and especially carring by elderly family members.
\end{abstract}

\section{Keywords: Risk, depression, elderly}

\section{PENDAHULUAN}

Penuaan merupakan suatu proses dalam kehidupan yang alami dan pasti akan dihadapi oleh setiap manusia dan tidak dapat dihindari. Penuaan ditandai dengan hilangnya secara perlahan-lahan kemampuan jaringan organ tubuh memperbaiki diri dan bersifat irreversibel. Lansia adalah merupakan tahapan akhir dari siklus kehidupan seseorang dan mengalami proses penuaan dengan terjadinya perubahan-perubahan pada berbagai aspek fisik atau fisiologi, psikologi, dan sosial (Miller, 2012). Perubahan akibat proses penuaan lansia yang kompleks menimbulkan lansia berpeluang sangat besar untuk mengalami penyakit daripada kelompok umur yang lain sehingga lansia juga termasuk ke dalam kelompok rentan (vulnerable population) (Stanhope \& Lancaster, 2004).

Karakteristik dari kelompok rentan tersebut dapat dilihat pada lansia berusia lebih dari 65 tahun dan mengalami perubahan kondisi fisik, psikologis, sosial yang lemah serta kondisi sulit mendapatkan pelayanan kesehatan dengan penghasilan yang kurang, pendidikan yang rendah, tidak memiliki tempat tinggal dan memiliki masa hidup yang lebih singkat akibat kondisi kesehatan (Allender, 2010; Maurer \& Smith, 2005).

Perubahan psikologis dan sosial juga dialami oleh lansia. Lansia memasuki masa pensiun atau penurunan peran dalam masyarakat akibat menurunnya produktivitas (Stanhope \& Lancaster, 2004; Miller, 2012). Lansia lebih banyak melakukan aktifitas sendiri di dalam rumah, sehingga lansia merasakan kondisi kesendirian. Demikian pula dengan kejadian hidup yang dialami lansia yaitu dengan adanya proses kehilangan pasangan hidup atau orang-orang yang dicintainya (Stanhope \& Lancaster, 2004; Friedman, Bowden \& Jones, 2003).

Penyakit kronis yang banyak ditemukan pada lansia di komunitas akibat faktor penuaan semua fungsi dan sistem tubuh adalah seperti diabetes mellitus, artritis, gangguan pendengaran, demensia, masalah jantung dan hipertensi (Anderson, 2011 dan Anderson, 2007). Hal inilah sangat perlu diperhatikan oleh tenaga kesehatan terutama oleh perawat komunitas dalam mengatasi masalah risiko depresi pada lansia. 


\section{METODE PENELITIAN}

\section{Desain Penelitian}

Penelitian ini menggunakan desain descriptive correlational dengan menggunakan pendekatan cross sectional study yaitu peneliti melakukan pengukuran atau penelitian dalam satu waktu.

\section{Sampel dan Sampling}

Sampel dalam penelitian ini adalah 78 Lansia di wilayah kerja Puskesmas Jekan Raya Kota Palangka Raya dengan menggunakan Purposive Sampling.

Teknik pengambilan sampel dalam penelitian ini adalah dengan menggunakan teknik probability sampling yaitu teknik pengambilan sampel yang memberikan kesempatan/peluang yang sama kepada setiap individu dalam populasi tersebut untuk menjadi sampel penelitian.

\section{Instrumen Penelitian}

Instrumen yang digunakan adalah kuesioner Geriatric Deppresion Scale (GDS) untuk mengukur tingkat depresi pada lansia dan pengkajian kemampuan fungsional lansia.

\section{Analisis Data}

Analisis data menggunakan analisis univariat yaitu untuk distribusi risiko depresi dan gangguan fungsional menetap pada lansia, dan analisis bivariat menggunakan Uji Chi Square dengan tingkat kemaknaan yang digunakan adalah 0,05 dengan CI (95\%).

\section{HASIL DAN PEMBAHASAN}

Risiko Depresi pada Lansia

Tabel 1 Distribusi Risiko Depresi dan Gangguan Fungsional Menetap pada Lansia di Wilayah Kerja Puskesmas Jekan Raya Kota Palangka Raya

\begin{tabular}{lcc}
\hline \multicolumn{1}{c}{ Variabel } & Frekuensi & Persentase \\
\hline Risiko Depresi & & \\
$\quad$ Tidak berisiko & 56 & 71,8 \\
$\quad$ Berisiko & 22 & 28,2 \\
Gangguan & & \\
Fungsional & & \\
Menetap & & \\
$\quad$ Tidak Ada & 46 & 59 \\
$\quad$ Ada & 32 & 41 \\
\hline \multicolumn{1}{c}{ Jumlah } & 78 & 100 \\
\hline
\end{tabular}

Tabel 1. memperlihatkan bahwa sebanyak 22 lansia $(28,2 \%)$ mengalami risiko depresi dan terdapat lansia yang mengalami gangguan fungsional menetap sebanyak 32 lansia (41\%).

Analisis Gangguan Fungsional Menetap dengan Risiko Depresi Lansia

Tabel 2. Gangguan Fungsional Menetap pada Lansia di Wilayah Kerja Puskesmas Jekan Raya Kota Palangka Raya

\begin{tabular}{ccccccc}
\hline Gangguan & \multicolumn{4}{c}{ Risiko Depresi } & \multicolumn{2}{c}{ Total } \\
\cline { 2 - 6 } $\begin{array}{c}\text { Fungsional } \\
\text { Menetap }\end{array}$ & \multicolumn{2}{c}{ Tidak Ada } & \multicolumn{2}{c}{ Ada } & & \\
\cline { 2 - 7 } & n & $\%$ & n & $\%$ & n & $\%$ \\
\hline Tidak ada & 44 & 95,7 & 2 & 4,3 & 46 & 100 \\
Ada & 12 & 37,5 & 20 & 62,5 & 22 & 100 \\
\hline Jumlah & 56 & 71,8 & 22 & 28,2 & 78 & 100 \\
\hline
\end{tabular}

Tabel 2. memperlihatkan hasil analisis hubungan gangguan fungsional menetap dengan risiko depresi lansia diperoleh bahwa sebanyak 20 lansia $(62,5 \%)$ memiliki gangguan fungsional menetap berisiko depresi. Hasil uji hipotesis Chi Square dua sisi (2-sided) diperoleh nilai $\mathrm{p}=0,000$, lebih kecil dari nilai $\alpha$ $=0,05$, sehingga Ho ditolak. Maka dapat disimpulkan ada hubungan yang signifikan antara gangguan fungsional menetap dengan risiko depresi pada lansia.

Dari hasil analisis diperoleh pula nilai $\mathrm{OR}=36,667$, artinya lansia yang memiliki gangguan fungsional menetap berpeluang 36,667 kali berisiko mengalami depresi dibandingkan dengan lansia yang tidak memiliki gangguan fungsional menetap. Nilai $\mathrm{OR}=36,667$ berarti kemungkinan lansia yang memiliki gangguan fungsional menetap akan berisiko $97,35 \%$ dari pada lansia yang tidak memiliki gangguan fungsional menetap $[\mathrm{p}=$ $\mathrm{OR} /(1+\mathrm{OR})]$.

Hasil analisis hubungan gangguan fungsional menetap dengan risiko depresi lansia diperoleh bahwa sebanyak 20 lansia $(62,5 \%)$ memiliki gangguan fungsional menetap berisiko depresi. Hasil uji hipotesis Chi Square dua sisi (2-sided) diperoleh nilai $\mathrm{p}=0,000$, lebih kecil dari nilai $\alpha=0,05$, sehingga Ho ditolak. Maka dapat disimpulkan ada hubungan yang signifikan antara gangguan fungsional menetap dengan risiko depresi pada lansia. Dari 
hasil analisis diperoleh pula nilai $\mathrm{OR}=36,667$, artinya lansia yang memiliki gangguan fungsional menetap berpeluang 36,667 kali berisiko mengalami depresi dibandingkan dengan lansia yang tidak memiliki gangguan fungsional menetap. Nilai $\mathrm{OR}=36,667$ berarti kemungkinan lansia yang memiliki gangguan fungsional menetap akan berisiko $97,35 \%$ dari pada lansia yang tidak memiliki gangguan fungsional menetap $[p=O R /(1+O R)]$.

Berdasarkan hasil analisis multivariat juga menunjukkan bahwa Odd Ratio (OR) dari variabel gangguan fungsional adalah 39 artinya Lansia yang mengalami gangguan fungsional menetap akan berisiko 39 kali lebih tinggi dibandingkan Lansia yang tidak mengalami gangguan fungsional menetap setelah dikontrol variabel usia, kejadian hidup dan penyakit lain (selain DM).

Hasil penelitian menunjukkan bahwa kondisi Lansia yang mengalami gangguan fungsional menetap seperti kondisi rambut yang mudah rontok, mata yang kabur, gangguan pada retina, kondisi impotensi psikogenik berisiko mengalami depresi. Kondisi tersebut disebabkan oleh suatu perubahan kondisi yang menetap dan mengganggu dalam pemenuhan kebutuhan Lansia.

Hasil penelitian ini sejalan dengan teori yang menyatakan bahwa penyebab depresi menurut Stuart (2009) adalah akumulasi ketidakpuasan, frustasi, kritikan pada diri sendiri tentang kejadian hidup sehari-hari tanpa adanya dukungan hal positif, stres dalam pekerjaan dan keluarga serta kehilangan. Penyebab depresi tidak hanya disebabkan oleh satu faktor saja, akan tetapi dapat saling berinteraksi dengan faktor yang lain, sehingga munculnya depresi (Townsend, 2009). Menurut Miller (2012), salah satu faktor risiko terjadinya depresi pada Lansia adalah gangguan fungsional menetap seperti akibat kelumpuhan, gangguan penglihatan, gangguan pergerakan, ketidakmampuan dalam melakukan aktifitas sehari-hari akibat intoleransi tubuh.

Gangguan fungsional tubuh lansia yang menetap membuat lansia merasa tidak berdaya dan putus asa. Lansia merasa tidak ada gunanya hidup di dunia dengan kondisinya tersebut. Lansia merasa tidak produktif dan tidak berguna bagi orang disekitar, bahkan merasa menjadi beban bagi orang lain. Perubahan kondisi kesehatan lansia yang membuat ketidakmampuannya lagi untuk bekerja keras, mudah lelah, penurunan penglihatan dan kondisi kecacatan karena amputasi merupakan gangguan fungsional menetap yang ditemukan pada lansia di Wilayah Kerja Puskesmas Jekan Raya.

Lansia yang mengalami risiko depresi di wilayah kerja puskesmas Jekan Raya akibat mengalami gangguan fungsional tubuh yang menetap terlihat memiliki harga diri yang rendah seperti selalu tunduk saat berbicara, tidak mau banyak berbicara dan malu untuk bergaul dengan lingkungan disekitarnya. Hal ini sangat penting diketahui bagi tenaga kesehatan dalam meningkatkan upaya promotif dan preventive di komunitas agar mencegah terjadinya gangguan fungsional menetap bagi lansia dan meningkatkan kesehatannya melalui pelayanan keperawatan di komunitas yang lebih optimal.

Menurut Ayranci dan Ozdag, 2006, dalam pemberian pelayanan kesehatan perawatan lansia di rumah, perawat sangat perlu melibatkan anggota keluarga karena sebagai orang terdekat bagi lansia. Blazer (2003) menyarankan bahwa strategi untuk meningkatkan kepuasan diri pada lansia akan mencegah depresi. Jika Lansia terus menerus melakukan berbagai aktivitas, maka Lansia akan memperoleh kepuasan dan kebahagiaan (Hikmawati \& Purnama, 2008). Hal ini merupakan hal yang perlu diperhatikan dalam perumusan tujuan intervensi keperawatan mencegah depresi terutama pada lansia. Penelitian ini telah dilaksanakan uji etik dengan surat keterangan kelaikan etik (ethical clearance) Nomor: 1792/UN24.9/KM/2017).

\section{KESIMPULAN DAN SARAN \\ Kesimpulan}

Gangguan fungsional yang menetap bagi Lansia merupakan faktor yang sangat mempengaruhi terjadinya risiko depresi pada Lansia dengan DM.

\section{Saran}

1. Perlu adanya dukungan kebijakan dari Dinas Kesehatan dan Puskesmas dalam mendukung pelayanan kesehatan Lansia DM di masyarakat dan keluarga melalui pelayanan puskesmas santun Lansia, perawatan dengan kunjungan rumah.

2. Perlu ditingkatkan pengetahuan dan kemampuan perawat komunitas dalam memberikan perawatan kesehatan bagi 
Lansia DM berupa pelayanan fisik maupun psikologis melalui pendidikan formal dan non formal dengan dengan strategi meningkatkan kepuasan diri pada lansia melalui kegiatan terapi aktivitas kelompok, kegiatan keagamaan dan penampilan minat dan bakat bagi Lansia di kelompok atau di masyarakat.

3. Perlu meningkatkan keterlibatan keluarga dalam mencegah derpresi pada Lansia di masyarakat melalui pemberdayaan keluarga sehat.

\section{DAFTAR PUSTAKA}

Anderson, E.T., \& McFarlane, J. M. (2011). Community as Partner: Theory and Practice in Nursing. Philadelphia: Wolters Kluwer Health/ Lippincott Williams \& Wilkins.

Anderson. M.A. (2007). Caring for Adults Holistically. Philadelphia: F.A. Davis Company.

Ayranci, U., \& Ozdag, N. (2006). Health of Elderly: Importance of Nursing and Family Medicine Care. The Internet Journal of Geriatrics and Gerintology, 1.
Blazer, D.G. (2003). Depression in Late Life: Review and Commentary. The Journal of Gerontology; Marc 2003: 58 A, 3. http:// proquest.umi.com. diperoleh tanggal 23 Oktober 2014.

Hikmawati, Eny dan Purnama, Akhmad (2008). Kondisi Kepuasan Hidup Lanjut Usia. Jurnal PKS vol. VII, No. 26 Desember 2008,79-93.

Friedman, M. M., Bowden, V.R., \& Jones, E.G. (2003). Family Nursing: Research, Theory, \& Practice. New Jersey: Pearson Education, Inc.

Miller, C.A. (2012). Nursing Care of Older Adult: Theory and Practice. Philadelphia: Lippincott Williams \& Wilkins.

Stanhope, M. dan Lancaster, J. (2010). Foundations of Nursing in The Community: Community - Oriented Practice. St. Louis Missouri: Mosby.

Stuart, G.W. (2009). Principles and Practice of Psychiatric Nursing. St. Louis: Mosby. 